\title{
Bezpośrednia współpraca człowiek-robot w spawalnictwie
}

\author{
Direct human-robot collaboration in welding
}

\section{Streszczenie}

W artykule omówiono zagadnienia związane z nową tendencją w robotyce, polegającą na coraz szerszym wykorzystywaniu tzw. robotów współpracujących, które dzielą swą przestrzeń roboczą z ludźmi. Przeprowadzony został literaturowy przegląd badań dotyczących programowania i eksploatacji tych robotów. Przedstawiono też niektóre aspekty stosunkowo nowej metody programowania robotów, zwanej programowaniem przez demonstrację. W szczególności autorzy podjęli próbę odpowiedzi na pytanie, czy i w jakim stopniu idea bezpośredniej współpracy człowiek-robot może być realizowana w spawalnictwie. Omówiono dostępne w literaturze informacje o badaniach w tym kierunku, prowadzonych w niektórych ośrodkach naukowych. Wśród różnych aspektów związanych z tą tematyką, zwrócono uwagę na zagadnienia dotyczące komunikacji człowiek-robot współpracujący. Zaprezentowano rozwijaną na Politechnice Warszawskiej koncepcję przystosowania systemu komunikacji głosowej pomiędzy człowiekiem i robotem do specyficznych wymagań, jakie narzuca idea robotów współpracujących.

Słowa kluczowe: spawanie zrobotyzowane; roboty współpracujące

\section{Wstęp}

Przeglądając opublikowane w ostatnich latach opracowania naukowe lub materiały informacyjne dotyczące robotyki, w tym robotyki przemysłowej, coraz częściej można się natknąć na termin "robot współpracujący", a w materiałach o charakterze popularyzatorskim również "cobot" (skrót od angielskiego terminu "COllaborative roBOT"), czasem występujący w wersji spolszczonej - „kobot". Coraz więcej ośrodków na całym świecie podejmuje badania dotyczące konstrukcji, sterowania oraz programowania tych robotów. Zainteresowanie to jest całkowicie zrozumiałe, gdyż roboty współpracujące wprowadzają zupełnie nową jakość w sposobie wykorzystywania maszyn manipulacyjnych do realizacji zadań, w tym zadań technologicznych [1,2]. Podstawowa różnica między tradycyjnym sposobem eksploatacji robotów przemysłowych a eksploatacją robotów współpracujących, polega na zniesieniu granic pomiędzy przestrzenią, w której może się poruszać człowiek i przestrzenią roboczą maszyny. Umożliwia to powstawanie zespołów roboczych ludzie-maszyny, które mogą wspólnie realizować określone cele, uzyskując synergetyczne efekty będące rezultatem połączenia mocnych stron człowieka (twórcze podejście do realizowanych zadań, elastyczność, łatwe uzyskiwanie precyzyjnych informacji o otoczeniu dzięki doskonale rozwiniętym zmysłom, zwłaszcza zmysłowi wzroku) z mocnymi stronami robota (powtarzalność, łatwość wywierania większej siły, brak zmęczenia).

Praktyczne stosowanie robotów współpracujących napotyka jednak na wiele ograniczeń, przede wszystkim związanych z koniecznością zapewnienia bezpieczeństwa człowiekowi [1]. Nie w każdej dziedzinie i nie do każdego zadania można je będzie wykorzystywać. W szczególności wiele problemów może się pojawić w przypadku prac spawalniczych, które z natury rzeczy wiążą się z pewnymi zagrożeniami dla zdrowia człowieka. Ponadto należy się zastanowić,

Mgr inż. Piotr Skrobek, dr hab. inż. Adam Rogowski - Politechnika Warszawska.

Autor korespondencyjny/Corresponding author: piotrskrobek.wipair@gmail.com 
czy i w jakich okolicznościach realizacja idei bezpośredniej współpracy człowiek-robot w spawalnictwie jest w ogóle celowa. Pewne prace badawcze w tym kierunku są już jednak prowadzone, i to z pozytywnymi efektami. Przykładowo, Fong i in. [3] przedstawili zaawansowane badania dotyczące wspólnego prowadzenia prac spawalniczych przez mieszany zespół, złożony z ludzi i robotów. Co prawda, zastosowanie opracowanych metod współpracy pomiędzy ludźmi i maszynami widzą oni głównie w realizacji zadań w przestrzeni kosmicznej lub na powierzchni obcych ciał niebieskich (znaczna część zespołu badawczego reprezentuje NASA), jednak można sobie wyobrazić podobne rozwiązania również w warunkach przemysłowych. Wśród informacji na temat badań dotyczących zastosowania robotów współpracujących w spawalnictwie są jednak i takie, które wprost się odnoszą do potencjalnych aplikacji przemysłowych. W dalszej części niniejszego artykułu dokonany zostanie przegląd badań i aplikacji związanych z robotami współpracującymi, ze szczególnym uwzględnieniem możliwości zastosowania tych robotów w spawalnictwie. Oprócz tego omówione będą zagadnienia dotyczące metody programowania robotów, zwanej programowaniem przez demonstrację. Należy bowiem zaznaczyć, że stosowanie tej metody w odniesieniu do robotów współpracujących wydaje się szczególnie obiecujące.

Bardzo ważnym aspektem funkcjonowania robotów współpracujących jest ich komunikacja z ludźmi. Bez prostej i niezawodnej komunikacji trudno sobie wyobrazić prawidłowe funkcjonowanie zespołów złożonych z ludzi i robotów. Jak wskazuje wielu badaczy, istotną rolę może tu odegrać komunikacja głosowa [4], zwłaszcza w kontekście coraz bardziej niezawodnych aparatów rozpoznawania mowy oraz systemów umożliwiających definiowanie quasi-naturalnych języków komend głosowych [5].

\section{Roboty współpracujące - szanse i wyzwania}

Jak stwierdzono wcześniej, zagadnienia związane z wykorzystaniem robotów współpracujących (czyli robotów, które dzielą z ludźmi wspólną przestrzeń roboczą i wspólnie z nimi realizują określone cele) w różnych dziedzinach, cieszą się już od szeregu lat coraz większym zainteresowaniem wielu ośrodków badawczych zajmujących się robotyką. W dotychczasowej praktyce przemysłowej nie przewidywało się tego typu współpracy. Roboty są oddzielone od pracowników i wykonują zaprogramowane czynności w zamkniętych strefach, po których pracownicy nie mogą się poruszać w trakcie pracy robota. Ograniczenia te wynikają ze względów bezpieczeństwa. Napędy robotów przemysłowych często charakteryzują się dużą mocą, a poszczególne ramiona przemieszczają się z bardzo dużą prędkością. W tych okolicznościach nawet przypadkowy, chwilowy kontakt robota z człowiekiem może doprowadzić do poważnego, wręcz śmiertelnego wypadku. Dlatego też bezpośredni kontakt człowieka - operatora z robotem przewidywany jest w zasadzie tylko podczas programowania, kiedy na napędy poszczególnych przegubów robota nałożone są znaczne ograniczenia dotyczące dopuszczalnej prędkości. W czasie realizacji zadania produkcyjnego oddziaływanie operatora na robota (nawet oddziaływanie pośrednie) jest zredukowane do minimum.

Zupełnie inna jest koncepcja oddziaływania człowieka na robota współpracującego. Dzięki obniżeniu kosztów oraz zwiększeniu dostępności zaawansowanych czujników, jak również powstaniu nowych środków komunikacji człowiek-maszyna, pojawiła się możliwość tworzenia zespołów roboczych złożonych z ludzi i robotów. Jak napisano wcześniej, stwarza to możliwość uzyskania synergetycznych efektów, będących rezultatem łączenia pracy precyzyjnych, powtarzalnych, niemęczących się robotów z pracą człowieka, który zostaje jeszcze bardziej odciążony od czynności trudnych i powtarzalnych, a może za to w pełni wykorzystać swój potencjał umysłowy. Takie połączenie może znacznie zwiększyć produktywność, jak również komfort pracy.

W tradycyjnych zastosowaniach robotów, człowiek - operator musiał w znacznej mierze dostosowywać swoje działania do wcześniej zaprogramowanego cyklu pracy robota, czyli w pewnym sensie był od niego uzależniony. Tymczasem realizacja idei robotów współpracujących wymaga, aby to program sterujący robotem odpowiednio reagował nawet na niespodziewane działania człowieka, zaś robot modyfikował parametry swojej pracy (w szczególności prędkość) w zależności od miejsca przebywania pracownika w przestrzeni roboczej maszyny. Takie zachowanie robota wydaje się być bardziej naturalne z punktu widzenia człowieka [6,7].

Należy zwrócić również uwagę, że realizacja koncepcji robotów współpracujących może się potencjalnie przyczynić do zmniejszenia miejsca na hali produkcyjnej, potrzebnego do pomieszczenia maszyn i urządzeń wchodzących w skład gniazd zrobotyzowanych. Wynika to z faktu, że robot współpracujący, wyposażony w odpowiednie mechanizmy zapewniające bezpieczeństwo ludziom znajdującym się w jego przestrzeni roboczej, nie wymaga ograniczania przestrzeni dostępnej dla ludzi (a przy okazji dla innych maszyn i urządzeń) poprzez stosowanie np. ogrodzeń bądź kurtyn bezpieczeństwa. Rysunek 1 przedstawia schemat wykorzystania przestrzeni roboczej przez człowieka i maszynę w przypadku robotów konwencjonalnych i robotów współpracujących.

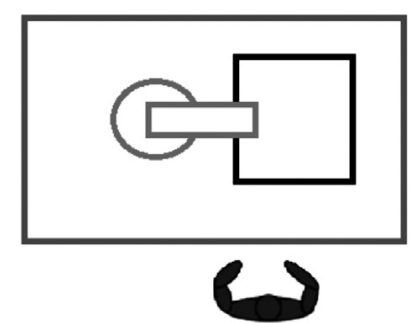

ROBOT KONWENCJONALNY

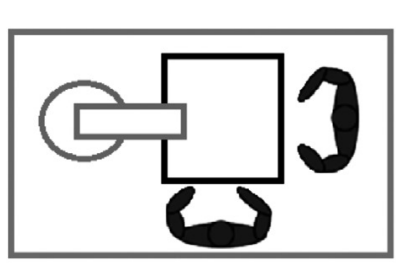

ROBOT WSPÓŁPRACUJĄCY
Rys. 1. Człowiek i robot w przestrzeni roboczej

Fig. 1. Human and robot in the workspace

Dodatkową zaletą robotów współpracujących jest możliwość zapewnienia im pewnej mobilności, dzięki czemu mogą wykonywać pracę w różnych miejscach na hali fabrycznej. W wyniku rezygnacji z wyznaczania stref bezpieczeństwa i budowania ogrodzeń, niezbędnych $w$ tradycyjnych rozwiązaniach, robot może zostać wyposażony w system transportowy. Nie musi on być już przywiązany do jednego, stałego miejsca na hali produkcyjnej, do którego wstęp ma tylko kilku wyspecjalizowanych pracowników. Byłoby to niemożliwe w przypadku tradycyjnych robotów przemysłowych, ze względu na zbyt duże ryzyko kolizji z człowiekiem i grożących przez to urazów.

Oczywiście, aby robot mógł realizować różne zadania w różnych miejscach, konieczne jest uwzględnienie tego w jego oprogramowaniu, które musi być odpowiednio modyfikowane bądź wymieniane. Problem ten daje się rozwiązać dzięki stosowaniu pamięci zewnętrznych (kart pamięci, urządzeń USB), w których można zapisywać programy sterujące robotem. Dzięki temu robot może być wykorzystywany w różny sposób, w zależności od aktualnego zapotrzebowania w danym przedsiębiorstwie przemysłowym $[8,9]$.

Producenci robotów współpracujących muszą się skupić nie tylko na obiektywnym zapewnieniu bezpieczeństwa człowiekowi, który ma pracować z robotem we wspólnej 
przestrzeni, ale brać również pod uwagę jego subiektywne poczucie bezpieczeństwa oraz komfort psychiczny, na co ma wpływ m.in. wygląd oraz sposób poruszania się robota. W literaturze pojawiły się opracowania $[7,10]$ opisujące metody realizujące te postulaty. Roboty współpracujące, ze względu na swoją fizyczną bliskość w stosunku do człowieka, powinny minimalizować obawy pracownika związane ze sposobem realizacji swych przemieszczeń. Ciekawym postulatem, wynikającym z przeprowadzonych badań, jest propozycja zmniejszenia możliwości ruchowych maszyny. Chociaż sam fakt wprowadzenia takiego ograniczenia może w niektórych sytuacjach zmniejszyć możliwości funkcjonalne robota, to z drugiej strony - jeśli pozwala na zwiększenie podobieństwa maszyny do człowieka - może prowadzić do wzrostu komfortu pracy operatora - współpracownika.

Weistroffer i in. [11], korzystając z narzędzi tzw. wirtualnej rzeczywistości, przeprowadzili związane z tym zagadnieniem badania, w ramach których zrealizowana została symulacja, odwzorowująca funkcjonowanie rzeczywistych linii montażowych. W badaniach tych zaangażowano doświadczonych operatorów zatrudnionych w przemyśle samochodowym. W rezultacie potwierdzono celowość stosowania robotów współpracujących w badanych sytuacjach. Przeprowadzono również analizę mającą na celu określenie optymalnej roboczej odległości pomiędzy człowiekiem i współpracującym z nim robotem, która zapewnia pracownikowi komfortowe warunki pracy przy jednoczesnym zachowaniu wysokiej efektywności procesu.

Ogólnie trzeba stwierdzić, że dzięki już potwierdzonym, jak również potencjalnym zaletom robotów współpracujących, ich stosowanie stanie się zapewne konkurencyjne w stosunku do tradycyjnych rozwiązań w wielu dziedzinach związanych z robotyką. W literaturze naukowej oraz w materiałach umieszczonych $w$ internecie można znaleźć wiele przykładów zastosowań robotów współpracujących [12:17], co wskazuje na lawinowo narastające zainteresowanie tym tematem.

\section{Bezpieczeństwo eksploatacji robotów współpracujących}

W przeważającej większości, tradycyjne roboty przemysłowe nie nadają się do bezpośredniej współpracy z ludźmi ze względu na brak wewnętrznych systemów zabezpieczających przed nieprzewidzianą kolizją, mogącą skutkować urazem, a nawet śmiercią człowieka. Jedną z nielicznych możliwości jest stosowanie zewnętrznych systemów rozpoznania obrazu bądź zewnętrznych systemów czujników zbierających sygnały z otoczenia. Może się to jednak okazać niewystarczającym rozwiązaniem dla zapewnienia bezpieczeństwa. To, co stanowi najistotniejsze zalety robotów przemysłowych, czyli duży udźwig oraz szybkość pracy, jest zarazem głównym powodem, dla którego roboty te mogą być bardzo niebezpieczne dla człowieka.

Wprowadzenie robotów współpracujących wymaga zupełnie nowego podejścia do wyznaczania standardów bezpieczeństwa. Dlatego też Międzynarodowa Organizacja Normalizacyjna zdecydowała o konieczności opracowania specyfikacji odpowiadającej nowym wymaganiom (ISO/TS 15066). Dokument ten zawiera wytyczne dotyczące zapewnienia bezpieczeństwa pracownikom przebywającym we wspólnej strefie z robotem. Mają one pomóc w budowaniu zrobotyzowanych stanowisk spełniających nowoczesne wymogi bezpieczeństwa [18].
Celem prowadzonych od dłuższego czasu prac badawczych jest istotne zwiększenie poziomu bezpieczeństwa człowieka pracującego wspólnie z robotem. Należy tu zaznaczyć, że z samej idei bezpośredniej współpracy człowiek-robot wynika dopuszczalność niepożądanego kontaktu maszyny z człowiekiem, np. zderzenie robota z operatorem. Nie można natomiast dopuścić do ryzyka utraty zdrowia przez człowieka. Ponadto nie może zostać przekroczony akceptowalny poziom bólu. Dlatego też w 2009 roku w Niemczech zostały ustanowione rekomendacje dotyczące dopuszczalnych sił oddziałujących na człowieka [19]. W wielu publikacjach naukowych $[20,21]$ prezentowane są wyniki teoretycznych analiz, określających wpływ różnych parametrów konstrukcji robota (np. masy) i parametrów jego ruchu (np. prędkości) na wartość siły, którą może on potencjalnie oddziaływać na człowieka w przypadku zaistnienia nieprzewidzianej kolizji, jak również wpływ wartości tej siły na możliwe skutki kolizji.

Behrens i Elkmann [22] przeprowadzili praktyczne doświadczenia z udziałem człowieka, aby potwierdzić rezultaty teoretycznych analiz. Badano wpływ uderzeń przedmiotów o różnej masie, prędkości i kształcie. Na podstawie uzyskanych wyników określono parametry, jakimi powinny się charakteryzować roboty współpracujące, aby zapewnić człowiekowi bezpieczeństwo. Kolizja z robotem uważana jest za tolerowaną, gdy nie powstanie otwarta rana oraz nie nastąpią obrażenia wewnętrzne.

Wyniki badań były wykorzystywane przez producentów robotów współpracujących. W rezultacie wprowadzono ograniczenia dotyczące masy robotów oraz prędkości rozwijanych przez napędy, aby zapewnić bezpieczne warunki pracy dla człowieka. Wprowadzano też coraz bardziej niezawodne systemy pomiarowe, mające na celu identyfikację pojawiających się sił, nieprzewidywanych w ramach realizowanego zadania technologicznego. Gdy człowiek przecina trajektorię ruchu robota i następuje zderzenie, dzięki czujnikom siły układ sterowania robota otrzymuje informację o kolizji, co implikuje zatrzymanie robota aż do momentu usunięcia przeszkody.

Aby potwierdzić poprawność działania systemów bezpieczeństwa bazujących na wbudowanych czujnikach siły, niektórzy producenci robotów umożliwili wykorzystanie sygnałów z tych czujników do programowania ruchów robota (np. instrukcja oddziaływania na obiekt z zadaną siłą). Może być to wykorzystane w wielu aplikacjach, w których siła oddziaływania na otoczenie jest istotnym parametrem realizowanej przez robota czynności [23].

\section{Roboty współpracujące w spawalnictwie}

Procesy spawalnicze ze względu na temperaturę, powstawanie szkodliwych oparów oraz inne zjawiska fizyczne i chemiczne, jakie zachodzą podczas spawania, są jednymi z bardziej niebezpiecznych procesów produkcyjnych. Z tego względu już od dłuższego czasu do realizacji tych procesów wykorzystywane są w szerokim zakresie roboty przemysłowe, które - z jednej strony zapewniając powtarzalność oraz stabilność procesu - zarazem odciążają człowieka i oddalają go od strefy niebezpiecznej. Spawanie zrobotyzowane ma wiele zalet w stosunku do spawania ręcznego: wzrasta wydajność, praca może odbywać się w sposób ciągły, uzyskiwane spoiny są powtarzalne nawet przy większych prędkościach spawania [24,25].

Ze względu na znaczny stopień zrobotyzowania prac spawalniczych, spawalnictwo jest wdzięcznym polem do rozwoju nowych idei dotyczących robotyki. Czy może to 
dotyczyć również robotów współpracujących? Zastosowanie tych robotów w spawalnictwie napotyka na szereg problemów, związanych głównie z bezpieczeństwem. Dlatego wydaje się, że realizacja idei współpracy człowiek-robot w tej dziedzinie będzie się raczej ograniczać do pewnych specyficznych zadań i sytuacji. Spróbujemy odpowiedzieć na pytanie, jakie to będą zadania i jakie sytuacje.

Coraz częściej prowadzi się na całym świecie badania związane $z$ nową metodą programowania robotów: tzw. programowaniem przez demonstrację. Wykazano, że w porównaniu z metodami tradycyjnymi, uczenie robotów tą metodą jest na ogół łatwiejsze i zabiera mniej czasu przy zachowaniu identycznej dokładności oraz powtarzalności [26]. W internecie można znaleźć wiele materiałów przedstawiających taki sposób programowania w praktyce $[27 \div 30]$. Nowa metoda programowania dotyczy w znacznej mierze robotów współpracujących. Pierwsze doświadczenia laboratoryjne w tym zakresie, związane ze spawalnictwem, zostały już przeprowadzone i opisane [31]. Nie jest to może klasyczna realizacja współpracy człowiek-robot, jednak pewne jej cechy tu występują (np. wykonywanie pracy fizycznej przez człowieka i robota w tej samej przestrzeni, choć nie w tym samym czasie). Spawacz wyposażony w uchwyt spawalniczy z naniesionymi markerami przeprowadza demonstracyjny proces spawania (bez włączonego łuku elektrycznego). Utworzony na bazie wielu kamer system wizyjny rejestruje serię pozycji uchwytu spawalniczego (włączając $w$ to również orientację kątową), co pozwala następnie na powtórzenie tych ruchów przez robota. Autorzy opracowania podają, że system ten pozwala na odwzorowanie trajektorii z dokładnością do milimetrów. Można założyć, że jego przemysłowe zastosowanie mogłoby znacznie wpłynąć na stopień wykorzystania funduszu czasu pracy robota (poprzez skrócenie czasu programowania), przez co eksploatacja systemów tego typu stałaby się ekonomicznie uzasadniona zwłaszcza w warunkach produkcji małoseryjnej, często realizowanej przez małe i średnie przedsiębiorstwa.

Warto nadmienić, że niektóre firmy produkujące roboty wprowadzają pewne rozwiązania techniczne, ułatwiające programowanie przez demonstrację np. firma Universal Robots [32], która stawia do dyspozycji użytkownika opcję „zwolnienia" napędów wszystkich osi przez operatora, dzięki czemu możliwy jest ręczny obrót każdego z przegubów w zakresie jego pracy $\left(\max .360^{\circ}\right)$. W tym przypadku realizacja programowania przez demonstrację polegałaby na ręcznym przemieszczaniu efektora robota (uchwytu spawalniczego) po określonej trajektorii. Inna opcja polega na dopuszczeniu tylko przemieszczeń translacyjnych efektora, wzdłuż konkretnej linii prostej. Znacznie ułatwia to ręczne prowadzenie robota wzdłuż prostej (co może być przydatne przy programowaniu robota do realizacji prostoliniowych spoin).

Inna możliwość, już ewidentnie mająca charakter bezpośredniej współpracy człowiek-robot, została zaprezentowana przez zespół badawczy z Uniwersytetu Technicznego w Tampere (Finlandia) w ramach projektu PATRA („Semiautomated solutions in man-machine systems"). Robot nie realizuje tam jednak spawania, tylko służy jako pozycjoner [33]. Samo spawanie jest realizowane przez człowieka. Nie jest to może sytuacja typowa, jednak łatwo sobie wyobrazić warunki, w których istniałoby zapotrzebowanie na takie rozwiązania np. jednostkowa produkcja wyrobów wymagających wykonania stosunkowo skomplikowanych i odpowiedzialnych spoin. Dzięki zastosowaniu robota - pozycjonera, człowiek ten ma dość komfortowe warunki pracy, gdyż nie musi zmieniać swojej pozycji przy spawa- niu odległych punktów, tylko wydaje polecenia zmiany pozycji materiału spawanego przez robota. Polecenia te są wydawane robotowi za pomocą gestów rozpoznawanych przez system wizyjny.

Trzy kamery używane do rejestrowania gestów operatora służą także do zapewnienia bezpieczeństwa człowiekowi w ramach systemu SafetyEYE [34]. Monitoruje on strefy bezpieczeństwa, przy czym informacja o aktualnej sytuacji wykorzystuje model trójwymiarowy. System ten jest w stanie określić strefę, w której aktualnie znajduje się spawacz. $\mathrm{Na}$ tej podstawie, wysyłane są do układu sterowania robota sygnały, powodujące zwolnienie bądź przyspieszenie realizowanych przemieszczeń. W przypadku, gdy człowiek znajdzie się zbyt blisko poruszającego się robota, ten zostaje natychmiast zatrzymany, a wznowienie pracy może nastąpić dopiero w wyniku realizowanej w ręczny sposób interwencji operatora. Na rysunku 2 zostały przedstawione przykładowe strefy bezpieczeństwa. Im bliżej robota znajduje się człowiek, tym mniejsza powinna być dopuszczalna prędkość maszyny. Jest to procedura charakterystyczna dla konwencjonalnych rozwiązań, jednak zamiast przycisku bezpieczeństwa zatrzymującego maszynę, zastosowano automatyczne monitorowanie stref bezpieczeństwa. Producent systemu SafetyEYE deklaruje zapewnienie norm bezpieczeństwa na maksymalnym obszarze $72 \mathrm{~m}^{2}$ oraz do wysokości $4 \mathrm{~m}$. W opublikowanym artykule [35] twórcy omawianego stanowiska poświęcili wiele uwagi zagadnieniom bezpieczeństwa i skutkom nieprzewidzianych wypadków.

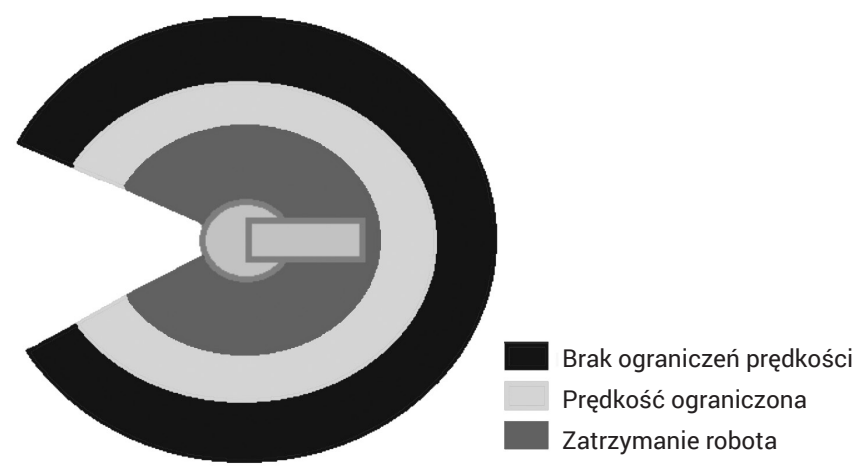

Rys. 2. Przykładowe strefy bezpieczeństwa, determinujące aktualną prędkość robota

Fig. 2. Exemplary safety zones, determining the current speed of the robot

Można się spodziewać, że w miarę rozwoju badań nad robotami współpracującymi, pojawią się nowe obszary ich zastosowań również w spawalnictwie.

Przy eksploatacji robotów współpracujących z pewnością trzeba będzie wykorzystywać wypracowane już rozwiązania, związane ze specyfiką prac spawalniczych, a dotyczące zarówno układów sterowania, jak i części mechanicznych robotów. Przykładowo, aby zmniejszyć ryzyko awarii, można zastosować specjalne osłony wykonane z materiałów odpornych na wysokie temperatury, co pozwala na ochronę wrażliwych części robota przed temperaturą, jak również przed odpryskami i odłamkami powstającymi w procesie spawania [29]. Jeśli chodzi o znane już rozwiązania, w które należałoby wyposażyć układy sterowania, to w przypadku robotów spawalniczych programowanych przez demonstrację, celowe byłoby korzystanie m.in. z zaawansowanych funkcji służących do automatycznej korekcji trajektorii. Umożliwiłoby to jeszcze szybsze programowanie trajektorii, gdyż mogłyby one być wyznaczane mniej dokładnie. Oczywiście stosowanie tych funkcji pozwoliłoby też na znaczne zwiększenie jakości i powtarzalności spoin. 
W szczególności warto byłoby stosować następujące metody, znane z aplikacji konwencjonalnych robotów spawalniczych:

a) Touch Sensing - wykrywanie kontaktu. Jest to funkcja, która w zasadzie nie wymaga stosowania żadnego dodatkowego oprzyrządowania, a bazuje na wbudowanych możliwościach źródła spawalniczego. Pozwala na określenie położenia części w przestrzeni i wprowadzeniu tzw. offsetów do zaprogramowanej trajektorii ruchu. Przed rozpoczęciem procesu spawania włączany jest tryb wyszukiwania przedmiotu, umożliwiający odnalezienie charakterystycznych punktów, w których dochodzi do zajarzenia łuku elektrycznego, bądź zamknięcia obwodu elektrycznego. Dla punktów tych układ sterowania zapamiętuje pozycje robota. Na tej podstawie cały program zostaje skorygowany, uwzględniając w ten sposób błąd pozycjonowania przedmiotu [36].

b) Through Arc Seam Tracking - jest to metoda polegająca na wykorzystaniu zależności natężenia prądu spawania od odległości elektrody od materiału. Wraz ze wzrostem tej odległości natężenie prądu maleje, natomiast przy jej zmniejszeniu - wzrasta. Na tej podstawie układ sterowania robota kompensuje odchylenie pozycji części spawanych od pozycji teoretycznej i w rezultacie zmienia parametry trajektorii. Zapewnia to powtarzalność oraz wysoką jakość spoiny. Przykład zastosowania tej funkcji został przedstawiony w dokumentacji robotów Fanuc [37,38].

c) Real Time Seam Tracking - jest to metoda wykorzystywana przy eksploatacji robotów spawalniczych wyposażonych w kamerę oraz system wizyjny, pozwalająca na rozpoznawanie i analizę obrazów, spawanych części wzdłuż wykonywanej spoiny. Dzięki temu można odpowiednio dostosować trajektorię, nawet gdy położenie przedmiotu zostanie zmienione w czasie pracy robota. Metoda ta została szerzej opisana przez Xu i in. [39]. Funkcję śledzenia spoiny można realizować także przy zastosowaniu czujników wykorzystujących inne zjawiska fizyczne np. prądy wirowe lub światło laserowe [40].

\section{Komunikacja człowiek-robot współpracujący}

Bardzo istotnym aspektem prawidłowego funkcjonowania robotów współpracujących jest ich komunikacja z człowiekiem. Ze względu na dzielenie wspólnej przestrzeni roboczej, a w szczególności ze względu na konieczność synchronizowania działań ukierunkowanych na realizację wspólnych celów, człowiek i robot muszą mieć zapewnione jak najbardziej niezawodne narzędzia wzajemnej komunikacji, które powinny być zarazem jak najbardziej dogodne w użytkowaniu przez człowieka. Trzeba mieć przy tym na względzie fakt, że funkcja człowieka będzie nieco inna niż tradycyjna funkcja operatora konwencjonalnych robotów. Najczęściej człowiek ten będzie sam zaangażowany w wykonywanie jakiejś pracy fizycznej, co wpłynie na ograniczenia w stosowaniu tradycyjnych środków komunikacji z maszynami jak np. różnego rodzaju pulpity sterownicze. W większym natomiast stopniu wykorzystywane będą takie środki jak komunikacja głosowa oraz rozpoznawanie gestów.

Przykładowo, womówionych wcześniejdoświadczeniach z robotem współpracującym, przeprowadzonych przez zespół badawczy z Tampere, gesty służą do wydawania poleceń robotowi. Robot, pełniący funkcję pozycjonera, współpracuje z człowiekiem - spawaczem poprzez ustawianie się w jednej z ośmiu możliwych pozycji, po zasygnalizowaniu stosownego żądania za pomocą odpowiedniego gestu.
Rozpoznawanie gestów jest realizowane przez system wizyjny, bazujący na trzech kamerach umieszczonych nad strefą roboczą. W rezultacie odpowiedni sygnał jest wysyłany do układu sterowania robota, a ten ustawia się w odpowiedniej pozycji.

Jeśli chodzi o komunikację głosową człowiek-maszyna, to warto nadmienić, że idea jej wykorzystania przy realizacji prac spawalniczych pojawiła się już dawno - dużo wcześniej, niż koncepcja robotów współpracujących. Powstał nawet patent dotyczący głosowego sterowania zasilaniem oraz prędkością podawania drutu przez spawarkę [41].

Profanter i in. [42] przedstawili wyniki badań nad efektywnością stosowania różnych środków komunikacji z robotami. Na grupie 30 użytkowników przeprowadzono eksperymenty dotyczące zadaniowo zorientowanego programowania robotów z wykorzystaniem różnych metod wprowadzania danych m.in. za pomocą gestów, ekranów dotykowych i mowy. Każda z metod miała być oceniona pod względem dogodności przez uczestników eksperymentu. Zastosowanie mowy okazało się wprawdzie łatwiejsze, niż to pierwotnie przewidywali użytkownicy, jednak było konkurencyjne w stosunku do innych metod tylko w bardzo ograniczonym zakresie (konkretnie: tylko przy wskazywaniu obiektów, aczkolwiek i tu miało przewagę wskazywanie gestem). Eksperymenty dotyczyły zadań takich jak przenoszenie przedmiotów (tzw. „pick and place"), montaż oraz spawanie. Należy jednak wyraźnie zaznaczyć, że badania te nie dotyczyły robotów współpracujących, których specyfika - jak wskazano wcześniej - będzie w znacznym stopniu determinowała stosowanie takich, a nie innych środków komunikacji. Z wyników przeprowadzonych eksperymentów należy więc wyciągnąć wniosek, że istnieje konieczność kontynuowania badań mających na celu zwiększenie dogodności stosowania nowych środków komunikacji z robotami, w szczególności komunikacji głosowej.

Badania związane z opracowaniem interfejsu człowiek-maszyna, bazującego na automatycznym rozpoznawaniu mowy, są prowadzone od szeregu lat m.in. na Politechnice Warszawskiej [43]. Komunikacja głosowa pomiędzy człowiekiem i robotem współpracującym wydaje się być - obok systemów bazujących na rozpoznawaniu gestów - najlepszym rozwiązaniem ze względu na fakt, że człowiek - sam wykonując pewną pracę fizyczną - często nie będzie mógł używać rąk do komunikowania się z maszyną. W tych zaś sytuacjach, gdy użycie rąk będzie możliwe, najlepszą metodą będzie zastosowanie gestów, gdyż nie wymaga ono przebywania w konkretnym miejscu np. w pobliżu pulpitu sterowniczego, co znacznie by ograniczało mobilność człowieka. Te dwie metody mogą się zresztą bardzo dobrze wzajemnie uzupełniać. Gesty nie są w stanie przekazać zbyt wielu informacji, podczas gdy mowa - jako najbardziej naturalny sposób komunikowania się pomiędzy ludźmi - może być nośnikiem informacji nawet bardzo złożonych, jednak pod warunkiem, że znany jest kontekst danej wypowiedzi słownej. W przeciwnym razie komendy głosowe musiałyby składać się z bardzo złożonych zdań, co w przypadku komunikacji człowiek-maszyna stanowiłoby rozwiązanie raczej mało praktyczne (a do tego zapewne dość zawodne, ze względu na znaczne prawdopodobieństwo błędnego rozpoznawania fonemów, składających się na długie wypowiedzi słowne). Tymczasem pojedynczy gest może zastąpić wiele słów np. przy określaniu kierunku pożądanego ruchu efektora robota. W ten sposób gesty są w stanie zapewnić kontekst dla komend głosowych i wyjaśnić występujące w nich niejednoznaczności [44]. W rezultacie komendy mogą być znacznie prostsze. 


\section{Podsumowanie}

Na podstawie ukazanych w artykule tendencji występujących we współczesnej robotyce, można wnioskować, że bezpośrednia współpraca człowiek-robot, oraz techniki programowania przez demonstrację będą już niebawem coraz szerzej wykorzystywane także w praktyce przemysłowej. W chwili obecnej nie są to już tylko ogólne koncepcje, lecz w ślad za nimi idą badania konkretnych zagadnień związanych z tą tematyką oraz rozwiązania techniczne wprowadzane przez firmy produkujące roboty. Jeśli chodzi o spawalnictwo, to występują tu być może większe ograniczenia wprowadzania tych koncepcji w życie, niż w niektórych innych dziedzinach, jednak prowadzone badania wykazują, że przy realizacji pewnych specyficznych zadań bezpośrednia współpraca człowiek-robot jest rozwiązaniem bardzo korzystnym. Przykładem może być ręczne spawanie z zastosowaniem robota pełniącego funkcję „inteligentnego” pozycjonera. Spełniony musi być jednak wtedy warunek zapewnienia niezawodnych i dogodnych dla użytkownika środków komunikacji człowiek-robot, takich jak komunikacja oparta na rozpoznawaniu gestów i na rozpoznawaniu mowy.

\section{Literatura}

[1] Zaeh M., Roesel W.: Safety aspects in a human-robot interaction scenario: a human worker is co-operating with an industrial robot, Progress in Robotics, Vol. 44(2), pp. 53-62, 2009.

[2] Weiss A. i in.: Exploring human-robot cooperation possibilities for semiconductor manufacturing, materiały konferencyjne: International Conference on Collaboration Technologies and Systems, Philadelphia, PA, USA, pp. 173-177, 2011.

[3] Fong T., Kunz C., Hiatt L., Bugajska M.: The Human-Robot Interaction Operating System, materiały konferencyjne: 1st ACM SIGCHI/SIGART conference on Human-robot interaction, Salt Lake City, Utah, USA pp. 41-48, 2006.

[4] Pires J.: The Industrial robot as a human coworker. the role of the speech interfaces, materiały konferencyjne: International Conference on Software Development for Enhancing Accessibility and Fighting Info-exclusion, Portugal, 2007.

[5] Rogowski A.: Analiza i synteza systemów sterowania głosowego w zrobotyzowanym wytwarzaniu, Prace Naukowe Politechniki Warszawskiej, Mechanika z. 244, 2012.

[6] Djuric A., Urbanic R., Rickli J.: A framework for collaborative robot (CoBot) integration in advanced manufacturing systems, SAE International Journal of Materials \& Manufacturing, Vol. 9(2), pp. 457-464, 2016.

[7] Baratta D.: Industrial collaborative robot design: a guideline for future design activity, materiały konferencyjne: International Conference of the Italian Association for Artificial Intelligence, Ferrara, Italy, 2015.

[8] Universal Robots on the move, [dostęp: 29-12-2017], https://blog.universal-robots.com/universal-robots-on-the-move

[9] Mobile robot colleagues on wheels increase productivity and worker safety at Scott Fetzer Electrical Group, [dostęp: 29-12-2017],

https://www.universal-robots.com/case-stories/scott-fetzer-electrical-group

[10] Zanchettin A., Bascetta L., Rocco P.: Acceptability of robotic manipulators in shared working environments through human-like redundancy resolution, Applied Ergonomics, Vol. 44(6), pp. 982-989, 2013.

[11] Weistroffer V. i in.: Assessing the acceptability of human-robot co-presence on assembly lines: a comparison between actual situations and their virtual reality counterparts, materiały konferencyjne: International Symposium on Robot and Human Interactive Communication, Edinburgh, United Kingdom, 2014

[12] Zaawansowane rozwiązanie robotyczne UR5 przyczynia się poprawy wyników finansowych FWP, [dostęp 29-12-2017],

https://www.universal-robots.com/pl/studia-przypadk\%C3\%B3w/ferdinand-wagner/

[13] Backman B., Renard C.: Simulating Human-Robot Collaboration: an example from cab assembly, praca dyplomowa, Department of Production Engineering, Royal Institute of Technology, Sweden, 2015.

[14] SCOTT Universal Robot welder, [dostęp 29-12-2017], https://www.youtube.com/watch?v=t3_-fUYqa60

[15] Universal Robots showcasing how our cobots work in various industries, [dostęp 29-12-2017],

https://www.youtube.com/watch?time_continue $=3 \& v=5 K 5 V Y m 8 z 4 n Y$

[16] Veloso M. i in.: CoBots: collaborative robots servicing multi-floor buildings, materiały konferencyjne: International Conference on Intelligent Robots and Systems, Algarve, Portugal, 2012.

[17] Kruger J., Lien T., Verl A.: Cooperation of human and machines in assembly lines, CIRP Annals, Vol. 58(2), pp. 628-646, 2009

[18] Jakubek K.: Bezpieczna współpraca ludzi i robotów,[dostęp 29-12-2017], http://automatykaonline.pl/Wywiady/Bezpieczna-wspolpraca-ludzi-i-robotow

[19] BG/BGIA risk assessment recommendations according to machinery directive. Design of workplaces with collaborative robots, BGIA - Institute for Occupational Safety and Health of the German Social Accident Insurance, Sankt Augustin, 2011.

[20] Haddadin S., Albu-Schhaffer A., Hirzinger G.: The role of the robot mass and velocity in physical human-robot interaction - Part I: Non-constrained blunt impacts, materiały konferencyjne: IEEE International Conference on Robotics and Automation, Pasadena, USA, pp. 1331-1338, 2008.

[21] Haddadin S., Albu-Schhaffer A., Frommberger M., Hirzinger G.: The role of the robot mass and velocity in physical human-robot interaction - Part II: Unconstrained Blunt Impacts, materiały konferencyjne: IEEE International Conference on Robotics and Automation, Pasadena, USA, pp. 1339-1345, 2008.
[22] Behrens R., Elkmann N.: Study on meaningful and verified thresholds for minimizing the consequences of human-robot collisions, materiały konferencyjne: IEEE International Conference on Robotics \& Automation, Hong Kong, 2014.

[23] Universal Robots - force move, [dostęp 29-12-2017], https://www.youtube.com/watch?v=szgvFYIY5ps

[24] Kruczyński M.: Zrobotyzowane stanowiska spawalnicze - przykłady konfiguracji, https://automatykab2b.pl/technika/2230-zrobotyzowane-stanowiskaspawalnicze-przyklady-konfiguracji\#.WjphclXibRb, [dostęp 05-12-2017].

[25] Cegielski P., Kolasa A., Sarnowski T.: Dostosowanie robotów do spawania elementów o obniżonej dokładności, Przegląd Spawalnictwa, Vol. 89(6), s. 25-28, 2011.

[26] Akgun B., Subramanian K.: Robot learning from demonstration: kinesthetic teaching vs. teleoperation, Georgia Institute of Technology, College of Computing, https://www.cc.gatech.edu/grads/k/ksubrama/files/HRIFinalBK.pdf, [dostęp 29-12-2017]

[27] Kinetiq teaching demo FabTech, [dostęp 29-12-2017], https://www.youtube.com/watch?v=3fMuGHBsGH8

[28] How to teach a linear welding path to a welding robot - kinetiq teaching by Robotiq, https://www.youtube.com/watch?list=PLsu4qiywzR4-dtDb8c4uK_ jxzkv4EskjS\&v=6BtgdmH8hrk, [dostęp 29-12-2017].

[29] Universal Robot welding - Olympus, [dostęp 29-12-2017], https://www.youtube.com/watch?v=0z7TE1Q1 rhw

[30] Universal Robots \& IRS MEXICO increased productivity by intuitive welding program, [dostęp 29-12-2017] https://www.youtube.com/watch?v=tGk2LQ5hDNE

[31] Antonelli D., Astanin S., Galetto M., Mastrogiacomo L.: Training by demonstration for welding robots by optical trajectory tracking, materiały konferencyjne: 8th CIRP Conference on Intelligent Computation in Manufacturing Engineering, Torino, pp. 145-150, 2013.

[32] Universal Robots has reinvented industrial robotics, [dostęp 29-12-2017], https://www.youtube.com/watch?v=eCep1HzfXwg\&list=PLsxbkRKkMlqIE06i TzinkDKAVgkatH3e3\&index $=4$

[33] Human robot co-operation welding workcell case, [dostęp 29-12-2017], https://www.youtube.com/watch?v=Kxw-SJd-j-o

[34] Wizyjny system bezpieczeństwa SafetyEYE, [dostęp 20-12-2017] https://www.pilz.com/pl-PL/eshop/00106002207042/SafetyEYE-Safe-camerasystem

[35] Malm T. i in.: Safety of Interactive Robotics - Learning from Accidents, Springer Science \& Business Media BV, Vol.2(3), pp. 221-227, 2010.

[36] Touch sensing \& seam tracking, [dostęp 29-12-2017] https://www.youtube.com/watch?v=AStw-K7Sq88

[37] FANUC - Through Arc Seam Tracking (TAST), LITHO IN U.S.A: FANUC Robotics America, 2005

[38] Robotics: Joint Sensing Technologies, Lincoln Electric, [dostęp 29-12-2017], http://www.lincolnelectric.com/en-us/support/process-and-theory/Pages/ intelligent-robotic-detail.aspx

[39] Xu Y., Yu H., Zhong J., Lin T., Chen S.: Real-time seam tracking control technology during welding robot GTAW process based on passive vision sensor, Journal of Materials Processing Technology, Vol. 212(8), pp. 1654-1662, 2012.

[40] Funkcje wspomagające proces spawania w oprogramowaniu ARC TOOL robotów Fanuc, http://roboforum.pl/artykul/funkcje-wspomagajace-processpawania-w-oprogramowaniu-arc-tool-robotow-fanuc, [dostęp 29-12-2017].

[41] Tunnell G., Pomernacki Ch., Gregg J.: Voice controlled welding system, Patent US 4641292A, 1987.

[42] Profanter S., Perzylo A., Somani N., Rickert M., Knoll A.: Analysis and semantic modeling of modality preferences in industrial human-robot interaction, IEEE/ RSJ International Conference on Intelligent Robots and Systems (IROS) Hamburg, Germany, 2015

[43] Rogowski A.: Industrially oriented voice control system, Robotics and Computer-Integrated Manufacturing, Vol. 28(3), pp. 303-315, 2012.

[44] Stiefelhagen R. i in.: Natural human - robot interaction using speech, head pose and gestures, IEEE/RSJ International Conference on Intelligent Robots and Systems, Sendai, Japan, Vol. 3, pp. 2422-2427, 2004 